\title{
PREVOTELLA SPECIES - THE MOST PREVALENT BLACK-PIGMENTED ANAEROBIC BACTERIA AMONG OROPHARYNGEAL ISOLATES OBTAINED FROM A SAMPLE OF HEALTHY YOUNG ADULTS
}

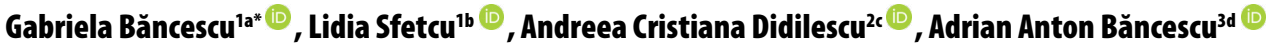 \\ 'Department of Microbiology, Faculty of Dental Medicine, "Carol Davila" University of Medicine and Pharmacy Bucharest, Bucharest, Romania \\ 2Department of Embryology, Faculty of Dental Medicine, "Carol Davila" University of Medicine and Pharmacy Bucharest, Bucharest, Romania \\ 3Department of Epidemiology, Faculty of Medicine, "Carol Davila" University of Medicine and Pharmacy Bucharest, Bucharest, Romania
}

aMD, MSc, PhD, Professor, Head; e-mail: gabi.bancescu@yahoo.com; ORCIDiD: https://orcid.org/0000-0003-2827-2465

bDMD, PhD, Assistant Professor; e-mail: lidia.ciobanu@ymail.com; ORCIDiD: https://orcid.org/0000-0002-4023-5053

'DMD, MPhil, PhD, Professor, Head, Vice-Dean; e-mail: andreea.didilescu@gmail.com; ORCIDiD: http://orcid.org/0000-0002-2915-5124

dMD, MSc, PhD, Associate Professor; e-mail: adrianbancescu@yahoo.com; ORCIDiD: https://orcid.org/0000-0003-4164-9810

Introduction The black-pigmented Prevotella - Porphyromonas group comprises members of the normal flora of the oral cavity, oropharyngeal, intestinal and genitourinary tract, but may be associated with various infections too. The purpose of this study was to identify the species of this anaerobic group which frequently colonize the oropharynx in clinically healthy young adults.

Methodology The microbiological investigation was carried out on a strain collection of 93 dark-pigmented anaerobic isolates originated from the oropharynx of healthy dental students, at the Department of Microbiology, Faculty of Dental Medicine, "Carol Davila" University of Medicine and Pharmacy - Bucharest. All isolates of Gram-negative bacilli were identified at the genus and species level by conventional methods, MASTRING ID (MAST Group Ltd., U.K.) and Rapid ID 32 A system (BioMérieux, France), while the isolates of anaerobic cocci were tested only by MASTRING ID.

Results The microscopy of the Gram-stained smears and the results of the MASTRING ID test performed with the 93 black-pigmented anaerobic isolates indicated that 77 strains were Gram-negative bacilli and/ or coccobacilli, while 16 strains were Gram-positive cocci. The identification of the Gram-negative bacilli at the species level concluded that 57 strains belonged to Prevotella denticola, 18 strains to Prevotella melaninogenica and 2 strains to Prevotella intermedia.

Conclusion P. denticola and P. melaninogenica might be considered the main species of the black-pigmented Prevotella-Porphyromonas group which colonize the oropharynx in healthy young adults. These species are usually beta-lactamase producers and their high rate of oropharyngeal colonization should be considered when antibiotics are needed in oral infections therapy.

\section{KEYWORDS}

Oropharynx, Microbiota, Anaerobes, Black-Pigmented Bacteria, Prevotella.

\section{INTRODUCTION}

The oropharynx comprises the palatine tonsils, tongue base, soft palate and posterior pharyngeal wall and is lined by a nonkeratinized stratified squamous epithelium [1]. The oropharynx mucosa comes in contact with saliva and nasopharyngeal secretion. The oropharynx microbiota is complex and comprises hundreds of microbial species [2,3], most of them organized in biofilms associated with the respective microenvironment [4]. About $80 \%$ of the local normal flora is represented by the viridans streptococci and commensal species of Haemophilus and Neisseria [5,6]. Besides different 
species of Mycoplasma, Corynebacterium and staphylococci, the oropharynx may harbor also pathogenic or potentially pathogenic bacteria like: Streptococcus pyogenes, Streptococcus agalactiae, Streptococcus dysgalactiae subsp. equisimilis, $S$. pneumoniae, Neisseria meningitidis, Haemophilus influenzae or Moraxella catarrhalis [6-14]. Some studies reported that the dominant bacteria of the normal oropharyngeal flora are the anaerobes [15]. The persistence of anaerobic bacteria is favored by the anaerobic conditions found into the depth of the biofilm covering the oropharyngeal mucosa, mainly due to the oxygen consumption by aerobic and facultative anaerobic bacteria. The mucosal convolutions and especially the tonsils crypts may be considered important anaerobic microhabitats. At these sites, the strictly anaerobes are found in high proportion with Prevotella being the most frequently isolated species $[16,17]$. Most Gram-negative anaerobic bacteria colonizing the oropharynx in healthy adults belong to the following genera: Prevotella, Fusobacterium, Leptotrichia and Veillonella [2,18-22]. Some researchers also found Porphyromonas at this site, but except for Prevotella spp., the other anaerobes were isolated in much smaller percentages than the facultative anaerobes, such as: streptococci, staphylococci and diphteromorphs [16]. The conclusion of a Norwegian-American research team that applied cultural-independent molecular techniques to determine the microbial diversity of the oral flora was that there is a distinctive dominant oral flora in healthy subjects, with site-specificity and high diversity [23]. The same team found an unexpected high diversity at tonsils level (more than 50 different species) with high variation between subjects [23].

Thus, Prevotella and Porphyromonas spp. were isolated from some subjects, but were missing in others who were harboring mostly bacteria belonging to the phylum Firmicutes [23].

Some bacterial community analysis indicated that the main group associated with the throat microbiota comprises: species belonging to Streptococcus and other genera of Firmicutes, species belonging to the family of Pasteurellaceae, Fusobacterium spp. and Actinomyces spp., while the main group associated with the tonsils includes species of Streptococcus, Mogibacterium and other Firmicutes, Fusobacterium spp., Prevotella spp. and members of the family Pasteurellaceae [24]. In healthy persons, the core microbiome plays a major role in homeostasis [25]. In children, an oropharyngeal microbiome similar to that of adults was described, but richer in Prevotella, Neisseria, Granulicatella, Porphyromonas and Fusobacterium [26]. At present high efforts are required for advanced research of normal flora of the oral cavity and oropharynx, estimating that future findings may substantially contribute to understanding the role played by the microorganisms with oral or oropharyngeal habitat in human pathology [23]. The present study intended to contribue to the investigation of black-pigmented Gram-negative anaerobic bacilli, since the anaerobic bacteria are not commonly cultivated by many microbiology laboratories. Thus, the aim of this study was to identify the species belonging to this bacterial category which colonize the oropharynx in healthy young adults most frequently.

\section{METHODOLOGY}

The microbiological investigation was performed on a collection of 93 black-pigmented anaerobic bacterial strains stored at $-70^{\circ} \mathrm{C}$, at the laboratory of the Department of Microbiology, Faculty of Dental Medicine, "Carol Davila" University of Medicine and Pharmacy (CDUMP) Bucharest. The respective strains originated from oropharyngeal swab samples collected from 29 male dental students and 64 female dental students, aged 20-34 years, at the same Microbiology department, in April 2018. They were second-year students, were clinically healthy and had not taken antibiotics in the last 6 months. Twenty-four of them were smokers: 7 male subjects and 17 female subjects. Prior to the present study, cultures from the 93 oropharyngeal swab samples were performed on Schaedler agar with 5\% sheep blood (BioMérieux, France), which were incubated in GENbox, with GENbox anaer sachet and Anaer indicator (BioMérieux, France), at $35^{\circ} \mathrm{C}$, for 10 days, with examination every $48 \mathrm{~h}$. All isolates that developed black pigment and showed negative results in the aerotolerance test were stored in cryobiles, at $-70^{\circ} \mathrm{C}$ and constituted the collection of strains used in the present study. At the beginning of this study conducted in the second semester of 2018, the black-pigmented anaerobic strains belonging to the above mentioned collection were checked for their morphotinctorial characteristics by microscopic examination of Gram-stained smear. All Gram-negative bacilli strains were further identified by the conventional methods, MAST ID MID8 ANAEROBE ID RING/MASTRING ID (MAST Group Ltd., U.K.) and Rapid ID 32 A system (BioMérieux, France). The presumptive identification of the Gram-negative bacilli strains was performed by testing their ability to grow in the presence of $20 \%$ bile (by streaking them on Bacteroides bile-esculin agar, BBE) and by testing their susceptibility to: vancomycin $(5 \mu \mathrm{g})$, kanamycin $(1000 \mu \mathrm{g})$, colistin sulphate $(10 \mu \mathrm{g})$, erythromycin $(60 \mu \mathrm{g})$, penicillin $\mathrm{G}$ (2 units) and rifampicin (15 $\mu \mathrm{g})$ by applying the MASTRING ID on blood agar plates (BioMérieux, France) seeded with bacterial inoculum adjusted to the turbidity of 2 McFarland standard. The plates were incubated in anaerobic atmosphere, at $35^{\circ} \mathrm{C}$, for $48 \mathrm{~h}$. Bacteroides fragilis ATCC 25285 was used as quality control. These tests were interpreted based on the indication mentioned in the textbooks of diagnostic microbiology [27], completed with the recommendation given by the MASTRING ID 


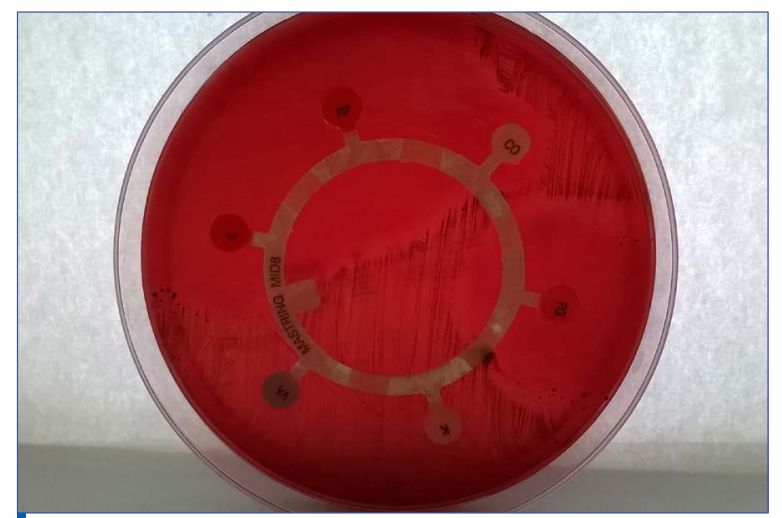

Figure 1. MASTRING ID test applied on a strain of black-pigmented Gram-negative anaerobic bacilli.

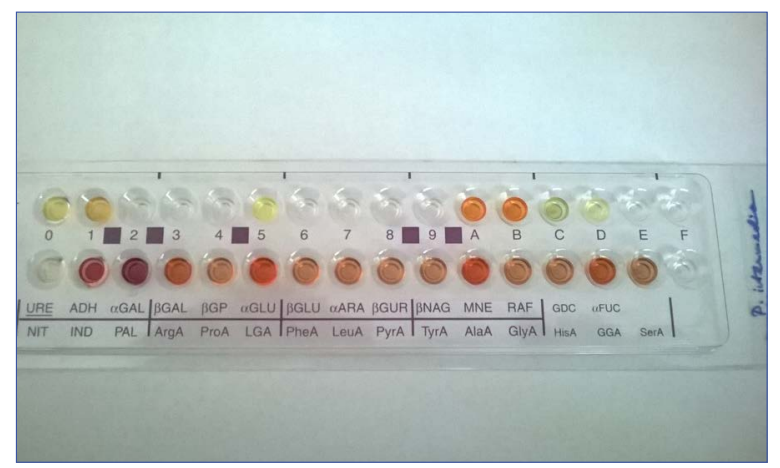

IFigure 3. P. intermedia strain identified by the Rapid ID 32 A system.

producer. In addition, the MASTRING ID test was also applied to the coccus-shaped anaerobic isolates.

The Fisher exact test was used to find any statistically significant association between smoking (data on this habit being received from students prior to this study, when oropharyngeal swab samples were collected) and oropharynx colonization with blackpigmented Gram-negative anaerobic bacilli species. The chosen significance level was $p \leq 0.05$.

\section{RESULTS}

The microscopic examination of the Gram-stained smears from the culture of dark-pigmented anaerobic strains indicated that 77 of the 93 isolates were Gram-negative bacilli and/or coccobacilli. The microscopy showed that the other 16 strains were Gram-positive cocci (arranged mainly in irregular clusters) and this was in complete agreement with the results of the MASTRING ID. Figure 1 illustrates the result of the MASTRING ID test applied to a strain of black-pigmented Gram-negative anaerobic bacilli (Fig. 1). The microbiological investigation carried out on the dark-pigmented Gram-negative anaerobic bacilli and/or coccobacilli isolates showed that all of them were susceptible to $20 \%$ bile, rifampicin and erythromycin, but resistant to kanamycin and vancomycin. The results concerning the susceptibility to colistin and penicillin $\mathrm{G}$ varied, 45 strains being found susceptible and 32 strains resistant to colistin, while only 19 strains were

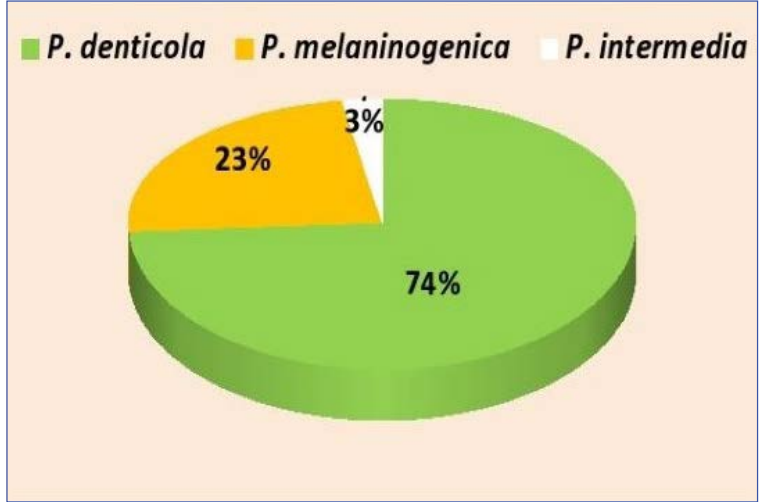

Figure 2. The distribution of the 77 strains of black-pigmented Gram-negative anaerobic bacilli by species.

found susceptible to penicillin. The interpretation of the tests according to the textbook of diagnostic microbiology [27] and MASTRING ID producer indicated that all these bacilli strains belonged to the genus Prevotella. The Rapid ID 32 A system indicated that 57 strains were Prevotella denticola, 18 strains were Prevotella melaninogenica and 2 strains were Prevotella intermedia (Fig. 2). In 5 subjects, pairs of $P$. denticola - P. melaninogenica were isolated. Twenty of the 72 students with black-pigmented Prevotella oropharyngeal colonization were smokers. Figure 3 presents the biochemical profile of a $P$. intermedia strain obtained with the Rapid ID 32 A gallery (Fig. 3). A $p$-value of 0.5737 was found when applying the Fisher exact test, indicating no statistically significant correlation between smoking and colonization of the oropharynx with black-pigmented Gramnegative anaerobic bacilli.

\section{DISCUSSION}

The normal oropharyngeal flora may show variability among healthy individuals due to external factors and ecological relationship. The investigation of the microbial relationship may contribute to clarifying many underlying aspects [28]. Anaerobic bacteria are not currently investigated by many laboratories due to the laborious and expensive work required. Porphyromonas and Prevotella (previously belonging to the genus Bacteroides) also include, besides non-pigmented species, dark-pigmented species like: Porphyromonas gingivalis, Porphyromonas endodontalis, Porphyromonas asaccharolytica, and Prevotella intermedia, Prevotella nigrescens, Prevotella melaninogenica, Prevotella loescheii, Prevotella denticola and Prevotella corporis, respectively [29]. This study focused on the investigation of the oropharynx colonization by dark-pigmented Prevotella and Porphyromonas species. The culture method allowed the isolation of the black-pigmented anaerobic strains. Because the development of dark-pigment is usually a delayed process, primary cultures (which were obtained prior to this study) were checked throughout the incubation period. The present study began with the selection of 
the bacilli strains among the 93 black-pigmented anaerobic isolates and continued with the species identification, based on both conventional and rapid methods. $P$. denticola, $P$. melaninogenica and $P$. intermedia were the only black-pigmented anaerobic bacilli species isolated from the oropharynx in this group of 93 healthy young dental students. The results obtained with the Rapid ID 32 A system showed very good to excellent identification for all but 6 strains. The identification at species level of the 6 strains mentioned above indicated $P$. denticola as the first choice and Prevotella oralis as the second choice. These isolates were considered to belong to $P$. denticola because $P$. oralis is known to not produce colonies with dark pigment. Atypical phenotypic characteristics of isolates can sometimes lead to misidentification of species. Therefore, the cultureindependent methods are highly recommended for the detection of anaerobic species. However, both culture-based method and detection by molecular techniques also have advantages and limitations. Previous studies performed in adults and children reported $P$. melaninogenica in a higher percentage in patients with tonsilar crypts who suffer from recurrent tonsillitis, compared to healthy subjects with adenotonsillar hyperplasia [17]. Recent studies reported that $P$. melaninogenica colonizes the tonsils in large quantities [30]. Isolates of this species are usually beta-lactamase producers [31] and this may explain the failure of penicillin treatment in recurrent tonsillitis [32]. The bacteria that produce enzymes that destroy the beta-lactam ring of penicillin indirectly protect penicillin-sensitive bacteria such as $S$. pyogenes [33]. Changes in the oropharyngeal ecology can variably affect the oropharyngeal microbiota. Smoking is one of the main external factors that can directly influence the composition of the upper airway microbiota [2]. Both active and passive smoking can contribute to colonization of the upper respiratory tract with pathogenic microorganisms [34,35] by impairing the immune response and favoring bacterial colonization, either by stimulating microbial adhesion to the epithelium or by other means [36,37]. Prevotella comprises commensal species from the human microbiota, which usually protect the upper respiratory tract against colonization of pathogenic bacteria [24,35]. Some studies have reported that nasopharynx in smokers frequently hosts Streptococcus pneumoniae, Haemophilus influenzae and Moraxella catarrhalis, while Prevotella is absent [24,35]. It has been observed that the oral cavity and the nasopharynx became colonized again with the normal resident flora when smoking was abandoned [38,39]. Recent research using univariate analysis and machine learning approaches has concluded that smokers compared to non-smokers are colonized with a greater number of species belonging to the genera: Megasphaera, Streptococcus, Veillonella, Atopobium, Eggerthella, Dorea, Anaerovorax, Eubacterium and to the family Erysipelotrichaceae [24]. Many of these bacteria can also be involved in oral infections. Some researchers found that significant changes occurring in the resident microbial population from oral and nasopharyngeal microbiota in smokers are correlated with higher frequencies of infections than in non-smokers [40]. Oropharyngeal flora varies due to many other factors, such as age and health status. In most studies focusing on the upper respiratory tract flora, mainly oral and nasopharyngeal flora have been investigated in children, the elderly and patients suffering from various diseases [41-47].

However, updated data on changes in oropharynx flora in healthy young adults are also needed.

Influenced by data from recent specialty literature, special attention was paid in the present research to analyze the association between smoking and colonization of oropharynx with black-pigmented Gram-negative anaerobic bacilli in the group of healthy young adults from whom the strains were isolated. Although the findings showed no statistically significant correlation, for a more accurate interpretation of the results, this study should be continued on a larger sample size.

It is important to understand that maintaining a normal oropharyngeal and nasopharyngeal microbiota is an important step in maintaining good health.

\section{CONCLUSIONS}

The findings of this study indicated $P$. denticola and $P$. melaninogenica as the main species of blackpigmented Gram-negative anaerobic bacilli that colonize oropharynx in healthy young adults. The well-known beta-lactamase activity of these bacteria should be strongly considered when antibiotics are needed in oral infection therapy.

\section{CONFLICT OF INTEREST}

The authors declare no conflict of interest.

\section{AUTHOR CONTRIBUTIONS}

All authors had equal contribution to the paper.

\section{ACKNOWLEDGEMENTS}

This study was part of the internal research plan for 2018 of the Department of Microbiology, Faculty of Dental Medicine, "Carol Davila" University of Medicine and Pharmacy (CDUMPB) and was carried out in co-operation with the Head of the Department of Embryology and a member of the Department of Epidemiology, "Carol Davila" University of Medicine and Pharmacy (CDUMPB). 


\section{REFERENCES}

1. Westra WH, Lewis JS. Update from the 4th edition of the World Health Organization classification of head and neck tumours: oropharynx. Head Neck Pathol. 2017;11(1):41-47. doi:10.1007/ s12105-017-0793-2.

[Full text links] [Free PMC Article] [CrossRef] [PubMed] Google Scholar Scopus

2. Charlson ES, Chen J, Custers-Allen R, et al. Disordered microbial communities in the upper respiratory tract of cigarette smokers. PLoS One. 2010;5:e15216. doi:10.1371/journal.pone.0015216. [Full text links] [Free PMC Article] [CrossRef] [PubMed] Google Scholar Scopus

3. de Steenhuijsen Piters WA, Sanders EA, Bogaert D. The role of the local microbial ecosystem in respiratory health and disease. Philos Trans R Soc Lond B Biol Sci. 2015;19:370(1675). pii:20140294. doi:10.1098/rstb.2014.0294.

[Full text links] [Free PMC Article] [CrossRef] [PubMed] Google Scholar Scopus

4. Marsh PD, Bowden GHW. Microbial community interactions in biofilm. In: Allison DG, Gilbert P, Lappin-Scott HM, Wilson $\mathrm{M}$, editors. Community structure and co-operation in biofilms. Cambridge, UK: Cambridge University Press; 2000.

[CrossRef] Google Scholar

5. Menon T. Understanding the viridians group streptococci: Are we there yet? Indian J Med Microbiol. 2016;34(4):421-426. doi:10.4103/0255-0857.195371.

[Full text links] [CrossRef] [PubMed] Google Scholar

6. Sheikhi R, Amin M, Rostami S et al. Oropharyngeal colonization with Neisseria lactamica, other nonpathogenic Neisseria species and Moraxella catarrhalis among young healthy children in Ahvaz, Iran. Jundishapur J Microbiol. 2015;8(3):e14813. doi:10.5812/ jjm.14813.

[Free PMC Article] [CrossRef] [PubMed] Google Scholar Scopus 7. Liu G, Tang CM, Exley RM. Non-pathogenic Neisseria: members of an abundant, multi-habitat, diverse genus. Microbiology. 2015;161(7):1297-1312. doi:10.1099/mic.0.000086.

[Full text links] [CrossRef] [PubMed] Google Scholar Scopus 8. Lewnard JA, Givon-Lavi N, Huppert A, et al. Epidemiological markers for interactions among Streptococcus pneumoniae, Haemophilus influenzae, and Staphylococcus aureus in upper respiratory tract carriage. J Infect Dis. 2016;15;213(10):1596-1605. doi:10.1093/infdis/jiv761.

[Full text links] [Free PMC Article] [CrossRef] [PubMed] Google Scholar Scopus

9. Bårnes GK, Brynildsrud OB, Børud B, et al. Whole genome sequencing reveals within-host genetic changes in paired meningococcal carriage isolates from Ethiopia. BMC Genomics. 2017;18:407. doi:10.1186/s12864-017-3806-3.

[Full text links] [Free PMC Article] [CrossRef] [PubMed] Google Scholar Scopus

10. Zhu L, Charbonneau ARL, Waller AS, et al. Novel genes required for the fitness of Streptococcus pyogenes in human saliva. $m S p h e r e$. 2017;2(6). pii:e00460-17. doi:10.1128/mSphereDirect.00460-17.

[Full text links] [Free PMC Article] [CrossRef] [PubMed] Google Scholar

11. McDonald M, Towers RJ, Andrews RM, et al. Epidemiology of Streptococcus dysgalactiae subsp. equisimilis in tropical communities, Northern Australia. Emerg Infect Dis. 2007;13:16941700. doi:10.3201/eid1311.061258.

[Full text links] [Free PMC Article] [CrossRef] [PubMed] Google Scholar Scopus

12. van der Mee-Marquet N, Fourny L, Arnault L, et al. Molecular characterization of human colonizing Streptococcus agalactiae strains isolated from throat, skin, anal margin, and genital body sites. J Clin Microbiol. 2008;46(9):2906-2911. doi:10.1128/ JCM.00421-08.

[Full text links] [Free PMC Article] [CrossRef] [PubMed] Google Scholar Scopus

13. Shaikh N, Leonard E, Martin JM. Prevalence of streptococcal pharyngitis and streptococcal carriage in children: a meta-analysis. Pediatrics. 2010;126:e557-64. doi:10.1542/peds.2009-2648. [Full text links] [CrossRef] [PubMed] Google Scholar Scopus 14. Principi N, Terranova L, Zampiero A, et al. Oropharyngeal and nasopharyngeal sampling for the detection of adolescent Streptococcus pneumoniae carriers. J Med Microbiol. 2012;63:393398. doi:10.1099/jmm.0.068726-0.

[Full text links] [CrossRef] [PubMed] Google Scholar Scopus

15. Brook I. Anaerobic bacteria in upper respiratory tract and head and neck infections: microbiology and treatment. Anaerobe. 2012;18(2):214-220.

[Full text links] [CrossRef] [PubMed] Google Scholar Scopus 16. Wilson M. Microbial inhabitants of humans: their ecology and role in health and disease. Cambridge, UK: Cambridge University Press; 2005.

[CrossRef] Google Scholar
17. Jensen A, Fagö-Olsen $\mathrm{H}$, Sørensen $\mathrm{CH}$, Kilian $\mathrm{M}$. Molecular mapping to species level of the tonsillar crypt microbiota associated with health and recurrent tonsillitis. PLOS ONE. 2013;8(2):e56418. doi:10.1371/journal.pone.0056418.

[Full text links] [Free PMC Article] [CrossRef] [PubMed] Google Scholar Scopus

18. Segata N, Haake SK, Mannon $\mathrm{P}$, et al. Composition of the adult digestive tract bacterial microbiome based on seven mouth surfaces, tonsils, throat and stool samples. Genome Biol. 2012;13:R42. doi:10.1186/gb-2012-13-6-r42.

[Full text links] [Free PMC Article] [CrossRef] [PubMed] Google Scholar Scopus

19. Garzoni C, Brugger SD, Qi W, et al. Microbial communities in the respiratory tract of patients with interstitial lung disease. Thorax. 2013;68:1150-1156. doi:10.1136/thoraxjnl-2012-202917.

[Full text links] [Free PMC Article] [CrossRef] [PubMed] Google Scholar Scopus

20. Gong $H$, Shi $Y$, Zhou $X$, et al. Microbiota in the throat and risk factors of laryngeal carcinoma. Appl Environ Microbiol. 2014;80(23):7356-7363. doi:10.1128/AEM.02329-14.

[Full text links] [Free PMC Article] [CrossRef] [PubMed] Google Scholar Scopus

21. Park H, Shin JW, Park S-G, Kim W. Microbial communities in the upper respiratory tract of

patients with asthma and chronic obstructive pulmonary disease. PLOS ONE. 2014;9:e109710. doi:10.1371/journal.pone.0109710.

[Full text links] [Free PMC Article] [CrossRef] [PubMed] Google Scholar Scopus

22. Whelan FJ, Verschoor CP, Stearns JC, et al. The loss of topography in the microbial communities of the upper respiratory tract in the elderly. Ann Am Thorac Soc. 2014;11(4):513-521. doi:10.1513/ AnnalsATS.201310-3510C.

[Full text links] [CrossRef] [PubMed] Google Scholar Scopus

23. Aas JA, Paster BJ, Stokes LN, et al. Defining the normal bacterial flora of the oral cavity. J Clin Microbiol. 2005:43(11):5721-5732. doi:10.1128/JCM.43.11.5721-5732.2005.

[Full text links] [Free PMC Article] [CrossRef] [PubMed] Google Scholar Scopus

24. Sharma N, Bhatia S, Sodhi AS, Batra N. Oral microbiome and health. AIMS Microbiol. 2018;4(1):42-66. doi:10.3934/ microbiol.2018.1.42.

[Free PMC Article] [CrossRef] [PubMed] Google Scholar

25. Zaura E, Keijser BJ, Huse SM, Crielaard W. Defining the healthy "core microbiome" of oral microbial communities. BMC Microbiol. 2009:9:259. doi: 10.1186/1471-2180-9-259.

[Full text links] [CrossRef] [Free PMC Article] [PubMed] Google Scholar Scopus

26. Stearns JC, Davidson CJ, McKeon S, et al. Culture and molecularbased profiles show shifts in bacterial communities of the upper respiratory tract that occur with age. ISME J. 2015;9(5):1246-1259. doi:10.1038/ismej.2014.250.

[Full text links] [CrossRef] [Free PMC Article] [CrossRef] [PubMed] Google Scholar Scopus

27. Engelkirk PG, Duben-Engelkirk J. Anaerobes of clinica importance. In: Mahon CR, Lehman DC, Manuselis G, editors. Textbook of Diagnostic Microbiology. Third ed. St. Louis, MI: Saunders Elsevier; 2007

[CrossRef] Google Scholar

28. Faust $\mathrm{K}$, Sathirapongsasuti JF, Izard J, et al. Microbial cooccurrence relationships in the human microbiome. PLoS Comput Biol. 2012;8(7):e1002606. doi:10.1371/journal.pcbi.1002606.

[Full Text Links] [CrossRef] [Free PMC Article] [PubMed] Google Scholar

29. Baumgartner JC, Siqeira JF Jr, Sedgley CM, Kishen A Microbiology of endodontic disease. In: Ingle Jl, Backland LK Baumgartner JC, editors. Ingle's Endodontics6. Sixth ed. Hamilton: BC Decker Inc; 2008.

[CrossRef] Google Scholar

30. De Steenhuijsen Piters WAA, Huijskens EGW, Wyllie AL, et al. Dysbiosis of upper respiratory tract microbiota in elderly pneumonia patients. ISME J. 2016;10(1):97-108. doi:10.1038/ ismej.2015.99.

[CrossRef] Google Scholar

31. Bahar H, Torun MM, Demirci M, Kocazeybek B. Antimicrobial resistance and $\beta$-lactamase production of clinical isolates of Prevotella and Porphyromonas species. Chemother. 2005;51(1):914. doi.org/10.1159/000084017.

[CrossRef] Google Scholar

32. Brook I. Penicillin failure in the treatment of streptococcal pharyngo-tonsillitis. Curr Infect Dis Rep. 2013;15(3):232-235. doi:10.1007/s11908-013-0338-0.

[Full text links] [CrossRef] [PubMed] Google Scholar Scopus 
33. Brook I. Treatment challenges of group A beta-hemolytic streptococcal pharyngo-tonsillitis. Int Arch Otorhinolaryngol. 2017;21(3):286-296. doi:10.1055/s-0036-1584294

[Full text links] [Free PMC Article] [CrossRef] [PubMed] Google Scholar Scopus

34. Brook I. The impact of smoking on oral and nasopharyngeal bacterial flora. J Dent Res. 2011;90(6):704-710. doi:10.1177/0022034510391794.

[Full text links] [CrossRef] [PubMed] Google Scholar Scopus

35. Brook I, Gober AE. Recovery of potential pathogens and interfering bacteria in the nasopharynx of smokers and nonsmokers. CHEST J. 2005;127(6):2072-2075. doi.org/10.1378/ chest.127.6.2072.

[Full text links] [CrossRef] [PubMed] Google Scholar Scopus 36. El Ahmer OR, Essery SD, Saadi AT, et al. The effect of cigarette smoke on adherence of respiratory pathogens to buccal epithelia cells. FEMS Immuno Med Microbiol. 1999;23(1):27-36. //doi. org/10.1111/j.1574-695X.1999.tb01713.x.

[Full text links] [CrossRef] [PubMed] Google Scholar Scopus 37. Tamashiro E, Xiong G, Anselmo-Lima WT, et al. Cigarette smoke exposure impairs respiratory epithelial ciliogenesis. Am J Rhinol Allergy. 2009;23(2):117-122. doi.org/10.2500\%2Faj ra.2009.23.3280.

[Full text links] [CrossRef] [PubMed] Google Scholar Scopus 38. Brook I, Gober AE. Effect of smoking cessation on the microbial flora. Arch Otolaryngol Head Neck Surg. 2007;133(2):135-138. [Full text links] [CrossRef] [PubMed] Google Scholar Scopus 39. Fullmer SC, Preshaw PM, Heasman PA. Smoking cessation alters subgingival microbial recolonization. J Dent Res. 2009;88(6):524528. doi.org/10.1177\%2F0022034509338676.

[Full text links] [CrossRef] [PubMed] Google Scholar Scopus 40. Arcavi L, Benowitz NL. Cigarette smoking and infection. Arch Intern Med. 2004;164(20):2206-2016. doi:10.1001/archinte. 164.20.2206.

[Full text links] [CrossRef] [PubMed] Google Scholar

41. Mager DL, Ximenez-Fyvie LA, Haffajee AD, Socransky SS. Distribution of selected bacterial species on intraoral surfaces. J Clin Periodontol. 2003;30(7):644-654. doi.org/10.1034/i.1600051X.2003.00376.X.

[Full text links] [CrossRef] [PubMed] Google Scholar
42. Konno $\mathrm{M}$, Baba $\mathrm{S}$, Mikawa $\mathrm{H}$, et al. Study of upper respiratory tract bacterial flora: first report. Variations in upper respiratory tract bacterial flora in patients with acute upper respiratory tract infection and healthy subjects and variations by subject age. Infect Chemother. 2006;12(2):83-96. doi.org/10.1007/s10156-0060433-3.

[Full text links] [CrossRef] [PubMed] Google Scholar

43. Konno M, Baba S, Mikawa $\mathrm{H}$, et al. Study of nasopharyngea bacterial flora. Second report. Variations in nasopharyngea bacterial flora in children aged 6 years or younger when administered antimicrobial agents. Part 1 J Infect Chemother. 2006;12(5):287-304. doi.org/10.1007/s10156-007-0533-8.

[Full text links] [CrossRef] [PubMed] Google Scholar

44. Konno M, Baba $\mathrm{S}$, Mikawa $\mathrm{H}$, et al. Study of nasopharyngeal bacterial flora. Second report. Variations in nasopharyngeal bacterial flora in children aged 6 years or younger when administered antimicrobial agents. Part 2. J Infect Chemother 2006;12(5):305-330. doi.org/10.1007/s10156-006-0469-4.

[Full text links] [CrossRef] [PubMed] Google Scholar

45. Kusahara DM, Canezin CCS, Peterlini MAS, Pedreira MLG. Oropharyngeal colonization, and gastric and tracheal bacterial translocation, in children experiencing mechanical ventilation. Acta Paul Enferm. 2012;25(3):393-400.

[CrossRef] Google Scholar

46. Lim Y, Totsika M, Morrison M, Punyadeera C. Oral microbiome: a new biomarker reservoir for oral and oropharyngeal cancers. Theranostics. 2017;7(17):4313-4321.

doi.org/10.7150\%2Fthno.21804

[Full text links] [CrossRef] [Free PMC Article] [CrossRef] [PubMed] Google Scholar

47. Ewan VC, Reid WDK, Shirley M, et al. Oropharyngeal microbiota in frail older patients unaffected by time in hospital. Front Cell Infect Microbiol. 2018;8:42. doi.org/10.3389/fcimb.2018.00042 [Full text links] [CrossRef] [PubMed] Google Scholar Scopus

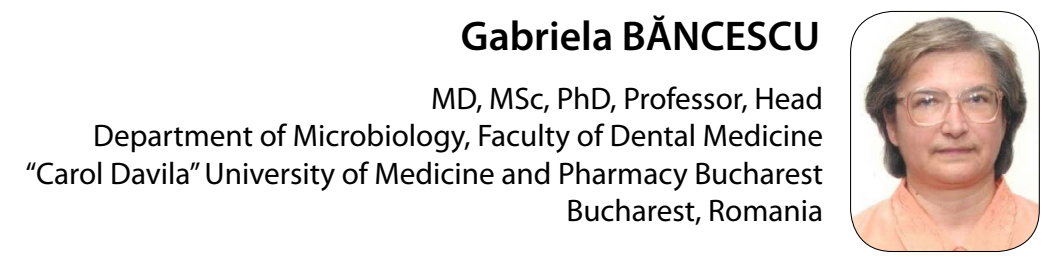

Professor Gabriela Băncescu is the Head of the Microbiology Department, Faculty of Dental Medicine, "Carol Davila" University of Medicine and Pharmacy Bucharest, Bucharest, Romania. She was awarded a Master's degree in Oral Microbiology by the University of Bergen, Norway. She was a member of the board of the European Society of Chemotherapy - Infectious Diseases. She is a member of the European Society of Clinical Microbiology and Infectious Diseases (ESCMID) and was a member of ESCMID Study Group for Anaerobic Infections. She was the Secretary General of the Romanian Society of Laboratory Medicine (20092014) and a member of the editorial board of the Bacteriol Virusol Parazitol Epidemiol, Infectio.ro and the Roum Arch Microbiol Immunol. At present, she is an Editor of the Stoma Edu J and Associate Editor of Rom J Rhinol. 


\section{Questions}

\section{Prevotella originated from the genus?}

a. Bacteroides;

ab. Fusobacterium;

ac. Tannerella;

Dd. Porphyromonas.

\section{Prevotella comprises species of?}

Da. Gram-positive anaerobic bacilli;

ub. Gram-negative anaerobic bacilli;

Dc. Gram-negative anaerobic cocci;

ad. Gram-negative aerobic bacilli.

\section{Exemples of black-pigmented anaerobic species?}

Da. Prevotella melaninogenica, Prevotella oralis and Prevotella nigrescens;

ab. Porphyromonas gingivalis, Porphyromonas endodontalis and Prevotella oralis;

ac. Prevotella melaninogenica, Prevotella intermedia and Prevotella nigrescens;

$\square$ d. Prevotella intermedia, Porphyromonas gingivalis and Prevotella oralis.

\section{The beta-lactamase?}

Da. Is never produced by black-pigmented anaerobic strains;

Db. Enhances the penicillin effect against anaerobic bacteria;

uc. Enhances the penicillin effect against aerobic bacteria;

d. Cleaves the beta-lactam ring of beta-lactam antibiotics.

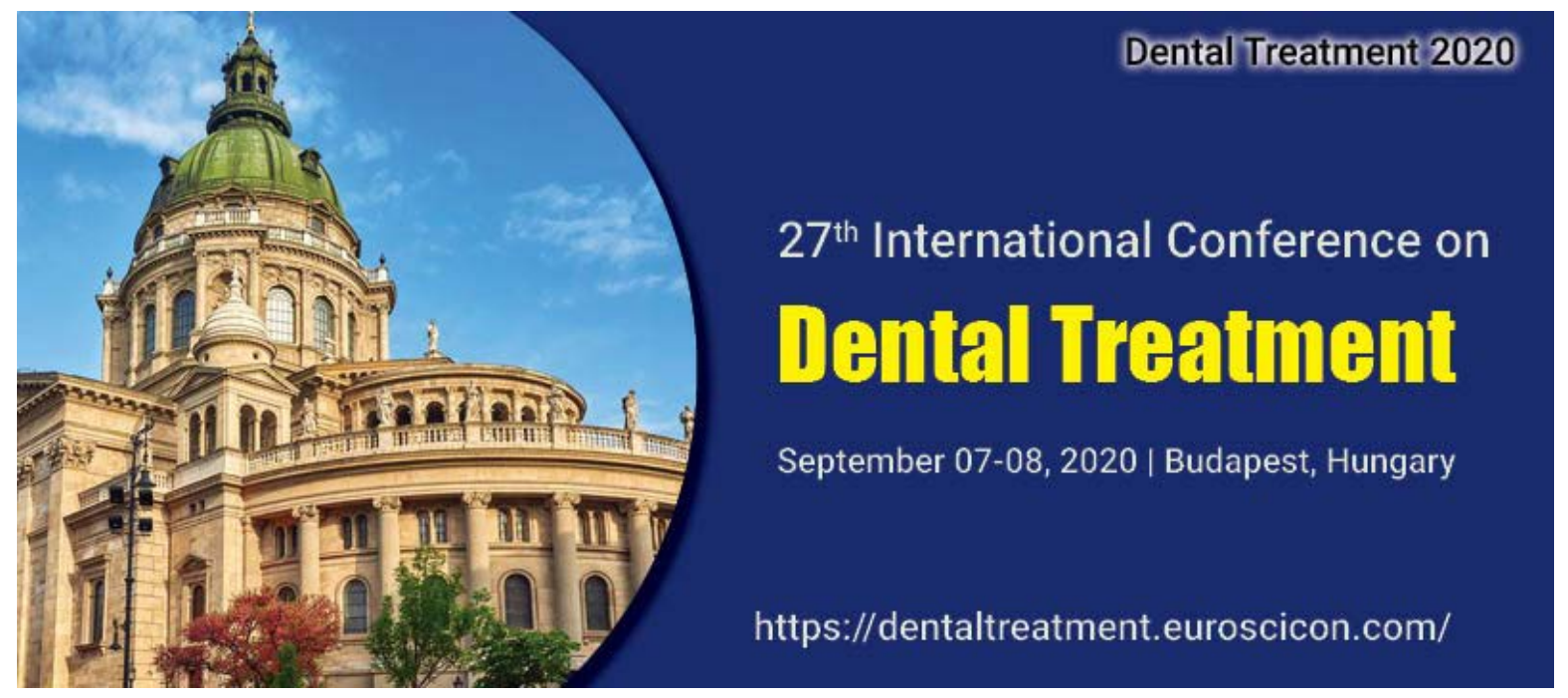

